\title{
Amino acid digestibility of heat damaged distillers dried grains with solubles fed to pigs
}

\author{
Ferdinando Nielsen Almeida ${ }^{1}$, John Kyaw Htoo ${ }^{2}$, John Thomson ${ }^{3}$ and Hans Henrik Stein ${ }^{1 *}$
}

\begin{abstract}
The primary objective of this experiment was to determine the effects of heat treatment on the standardized ileal digestibility (SID) of amino acids (AA) in corn distillers dried grains with solubles (DDGS) fed to growing pigs. The second objective was to develop regression equations that may be used to predict the concentration of SID AA in corn DDGS. A source of corn DDGS was divided into 4 batches that were either not autoclaved or autoclaved at $130^{\circ} \mathrm{C}$ for 10,20 , or $30 \mathrm{~min}$. Four diets containing DDGS from each of the 4 batches were formulated with DDGS being the only source of $\mathrm{AA}$ and $\mathrm{CP}$ in the diets. A N-free diet also was formulated and used to determine the basal endogenous losses of CP and AA. Ten growing pigs (initial BW: $53.5 \pm 3.9 \mathrm{~kg}$ ) were surgically equipped with a T-cannula in the distal ileum and allotted to a replicated $5 \times 4$ Youden square design with 5 diets and 4 periods in each square. The SID of CP decreased linearly $(P<0.05)$ from $77.9 \%$ in non-autoclaved DDGS to $72.1,66.1$, and $68.5 \%$ in the DDGS samples that were autoclaved for 10, 20, or 30 min, respectively. The SID of lysine was quadratically reduced $(P<0.05)$ from $66.8 \%$ in the non-autoclaved DDGS to $54.9,55.3$, and $51.9 \%$ in the DDGS autoclaved for 10 , 20, or 30 min, respectively. The concentrations of SID Arginine, Histidine, Leucine, Lysine, Methionine, Phenylalanine, or Threonine may be best predicted by equations that include the concentration of acid detergent insoluble $\mathrm{N}$ in the model $\left(r^{2}=0.76,0.68,0.67,0.84,0.76,0.73\right.$, or 0.54 , respectively). The concentrations of SID Isoleucine and Valine were predicted $\left(r^{2}=0.58\right.$ and 0.54 , respectively) by the Lysine:CP ratio, whereas the concentration of SID Tryptophan was predicted $\left(r^{2}=0.70\right)$ by the analyzed concentration of Tryptophan in DDGS. In conclusion, the SID of AA is decreased as a result of heat damage and the concentration of SID AA in heat-damaged DDGS may be predicted by regression equations developed in this experiment.
\end{abstract}

Keywords: Amino acids, Digestibility, Distillers dried grains with solubles, Heat damage

\section{Background}

Production of corn distillers dried grains with solubles (DDGS) involves a drying step in which the temperature at the dryer inlet may be above $500^{\circ} \mathrm{C}$, while the temperature at the dryer discharge may be above $100^{\circ} \mathrm{C}$ [1]. Application of heat to feed ingredients may initiate Maillard reactions, which decrease the concentration and digestibility of Lysine and other amino acids (AA) [2-4]. Lysine is particularly susceptible to undergo Maillard reactions because of its free amino group, which easily reacts with reducing sugars. If the amino group of an AA reacts with a reducing sugar to form early or advanced Maillard reaction products, it becomes unavailable to pigs

\footnotetext{
* Correspondence: hstein@illinois.edu

${ }^{1}$ Department of Animal Sciences, University of Illinois, 1207 W Gregory Dr, Urbana, IL 61801, USA

Full list of author information is available at the end of the article
}

[2,5]. During the acid hydrolysis step of AA analysis, however, Lysine that has reacted with reducing sugars is partially recovered, thus leading to an overestimation of available Lysine. For this reason, determination of reactive Lysine, color, and the Lysine: $\mathrm{CP}$ ratio have been suggested as approaches to estimate the availability of Lysine in DDGS [2,6-9]. Heat damage and Maillard reactions have been described in different sources of corn DDGS $[2,10,11]$. However, if different sources of DDGS are used, it is difficult to distinguish between effects of heat damage and other factors influencing AA digestibility. Gradual increases in heating of a specific source of DDGS will result in reduced concentrations of reactive Lysine $[2,6]$. There is, however, no information about effects of increasing time of heating of a specific source of DDGS on in vivo AA digestibility, and on the changes in reactive Lysine, and the Lysine: $\mathrm{CP}$ ratio. Prediction of the concentration of

\section{Biomed Central}


digestible AA and $\mathrm{CP}$ from the concentration of reactive Lysine and the Lysine:CP ratio in corn DDGS that was purposefully heat-damaged have not been reported. Thus, the primary objective of this experiment was to determine effects of heat treatment on the apparent ileal digestibility (AID) and the standardized ileal digestibility (SID) of AA in corn DDGS fed to growing pigs. A second objective was to develop prediction equations that may be used to predict the concentration of SID AA in corn DDGS.

\section{Materials and methods}

The Institutional Animal Care and Use Committee at the University of Illinois reviewed and approved the protocol for this experiment. Pigs used in the experiment were the offspring of G-performer boars and F-25 females (Genetiporc, Alexandria, MN).

\section{Animals, housing, and experimental design}

Ten growing pigs (initial BW: $53.5 \pm 3.9 \mathrm{~kg}$ ) were surgically equipped with a T-cannula in the distal ileum [12] and allotted to a replicated $5 \times 4$ Youden square design with 5 diets and 4 periods in each square. Pigs were individually housed in a controlled environment in pens $(1.2 \mathrm{~m} \times 1.5 \mathrm{~m})$ equipped with a feeder and a nipple waterer.

\section{Diets and feeding}

Distillers dried grains with solubles was obtained from Poet Nutrition (Sioux Falls, SD) and analyzed for CP and AA. The DDGS was divided into 4 batches that were not autoclaved or autoclaved at $130^{\circ} \mathrm{C}$ for 10,20 , or $30 \mathrm{~min}$ (Table 1). Four diets containing DDGS from each of the 4 batches were formulated, with DDGS being the only source of AA and CP in the diets (Tables 2 and 3). A N-free diet also was formulated and used to determine the basal endogenous losses of $\mathrm{CP}$ and $\mathrm{AA}$ in the pigs. Diets were supplied with vitamins and minerals to meet or exceed the requirement estimates for growing pigs [13]. Chromic oxide also was included (0.4\%) in diets and used as an indigestible marker.

The amount of feed provided was calculated as 2.5 times the maintenance requirement of energy (i.e., $106 \mathrm{kcal}$ of $\mathrm{ME} / \mathrm{kg} \mathrm{BW}{ }^{0.75} ;$ [13]). Pigs were fed once daily at $0800 \mathrm{~h}$. At the beginning of each period, feed allowance was adjusted based on the BW of each pig. Water was available at all times.

\section{Sample collection}

Each period consisted of $7 \mathrm{~d}$. The initial $5 \mathrm{~d}$ were considered an adaptation period to the diet. On d 6 and $\mathrm{d} 7$, ileal digesta were collected for $8 \mathrm{~h}$ using standard operating procedures. A plastic bag was attached to the cannula barrel and digesta flowing into the bag were collected. Bags were replaced whenever they were filled with digesta, or at least once every $30 \mathrm{~min}$ and immediately frozen at $-20^{\circ} \mathrm{C}$ to prevent bacterial degradation of $\mathrm{AA}$ in the digesta.

\section{Chemical analyses}

At the conclusion of the experiment, ileal digesta samples were thawed, mixed within animal and diet, and a sub-sample was lyophilized, ground to pass a $1 \mathrm{~mm}$ screen, and analyzed. A sample of each diet and of each batch of DDGS was collected at the time of diet mixing. Diets, ingredients, and ileal samples were analyzed for AA by ion-exchange chromatography with postcolumn derivatization with ninhydrin. Amino acids were oxidized with performic acid, which was neutralized with $\mathrm{Na}$ metabisulfite [14,15]. Amino acids were liberated from the protein by hydrolysis with $6 \mathrm{~mol} / \mathrm{L} \mathrm{HCL}$ for $24 \mathrm{~h}$ at $110^{\circ} \mathrm{C}$ and quantified with the internal standard by measuring the absorption of reaction products with ninhydrin at $570 \mathrm{~nm}$. Tryptophan was determined by HPLC with fluorescence detection (extinction $280 \mathrm{~nm}$, emission $356 \mathrm{~nm}$ ), after alkaline hydrolysis with barium hydroxide octahydrate for $20 \mathrm{~h}$ at $110^{\circ} \mathrm{C}$ [16]. Diets, ingredients, and ileal samples also were analyzed for DM (method 935.29; [17]), and for CP following the Dumas procedure (method 968.06; [17]). Diets and ileal samples were analyzed for chromium (method 990.08; [17]). Ingredients were analyzed for acid detergent fibre (ADF; Method 973.18; [17]), neutral detergent fibre (NDF) [18], lignin (method 973.18 (A-D); [17]), ash (method 942.05; [17]), for total fat by acid hydrolysis using $3 \mathrm{~mol} / \mathrm{L} \mathrm{HCl} \mathrm{[19]}$ followed by crude fat extraction with petroleum ether (method 2003.06; [17]), total reducing sugars [20], and furosine [8]. The concentration of acid detergent insoluble nitrogen (ADIN) in ingredients was determined as the concentration of $\mathrm{N}$ in the ADF fraction (method 990.03; [17]).

\section{Calculations and statistical analysis}

Values for AID and SID of CP and AA were calculated [21]. The Lysine:CP ratio in each DDGS sample was calculated by expressing the concentration of Lysine in the sample as a percentage of the $\mathrm{CP}$ in the sample. The concentration of reactive Lysine (\%) was calculated by the following equation:

$$
\begin{aligned}
\text { Reactive Lysine }= & \text { total Lysine }(\%) \\
& -[\text { furosine }(\%) \div 0.32 \times 0.40]
\end{aligned}
$$

Data were analyzed using the MIXED procedure (SAS Institute Inc., Cary, NC). Normality of the data and the presence of outliers were evaluated using the UNIVARIATE procedure of SAS. One outlier was identified and removed from the data. The model included dietary treatment as fixed effect and pig and period as random effects. Linear and quadratic effects of increasing time of heat treatment 
Table 1 Chemical composition of distillers dried grains with solubles

\begin{tabular}{|c|c|c|c|c|}
\hline \multirow[b]{3}{*}{ Item } & \multicolumn{4}{|c|}{ Distillers dried grains with solubles } \\
\hline & \multirow[b]{2}{*}{ Non-autoclaved } & \multicolumn{3}{|c|}{ Autoclaved at $130^{\circ} \mathrm{C}$} \\
\hline & & $10 \mathrm{~min}$ & $20 \mathrm{~min}$ & $30 \mathrm{~min}$ \\
\hline Dry matter, \% & 93.21 & 92.43 & 90.91 & 94.47 \\
\hline Ash, \% & 5.25 & 5.08 & 5.17 & 5.06 \\
\hline Crude protein (CP), \% & 27.91 & 27.44 & 26.51 & 27.05 \\
\hline $\mathrm{AEE}_{1}^{1} \%$ & 10.20 & 12.73 & 12.83 & 9.25 \\
\hline Lysine: CP ratio ${ }^{2}$ & 2.94 & 2.37 & 2.75 & 2.51 \\
\hline Furosine, $\%$ & 0.015 & 0.009 & 0.006 & 0.008 \\
\hline Reactive Lysine ${ }^{3}$ & 0.80 & 0.64 & 0.72 & 0.67 \\
\hline Acid detergent fibre, $\%$ & 7.96 & 11.05 & 9.85 & 10.89 \\
\hline Neutral detergent fibre, $\%$ & 31.29 & 33.23 & 33.32 & 32.40 \\
\hline Acid detergent lignin, \% & 0.88 & 2.06 & 1.73 & 2.57 \\
\hline Acid detergent insoluble $\mathrm{N}_{1}^{4} \%$ & 0.12 & 0.53 & 0.42 & 0.55 \\
\hline Reducing sugars, \% & 0.78 & 0.60 & 0.88 & 0.65 \\
\hline \multicolumn{5}{|l|}{ Indispensable AA, \% } \\
\hline Arginine & 1.24 & 1.10 & 1.19 & 1.10 \\
\hline Histidine & 0.71 & 0.67 & 0.70 & 0.67 \\
\hline Isoleucine & 0.97 & 0.91 & 0.96 & 0.93 \\
\hline Leucine & 2.92 & 2.82 & 2.89 & 2.78 \\
\hline Lysine & 0.82 & 0.65 & 0.73 & 0.68 \\
\hline Methionine & 0.53 & 0.49 & 0.52 & 0.50 \\
\hline Phenylalanine & 1.24 & 1.17 & 1.21 & 1.17 \\
\hline Threonine & 1.02 & 0.98 & 1.01 & 0.98 \\
\hline Tryptophan & 0.22 & 0.20 & 0.20 & 0.20 \\
\hline Valine & 1.26 & 1.19 & 1.26 & 1.23 \\
\hline \multicolumn{5}{|l|}{ Dispensable AA, \% } \\
\hline Alanine & 1.90 & 1.83 & 1.87 & 1.82 \\
\hline Aspartic acid & 1.75 & 1.66 & 1.73 & 1.66 \\
\hline Cysteine & 0.55 & 0.50 & 0.52 & 0.50 \\
\hline Glutamine & 4.43 & 4.31 & 4.41 & 4.26 \\
\hline Glycine & 1.08 & 1.04 & 1.09 & 1.04 \\
\hline Proline & 2.21 & 2.06 & 2.13 & 2.04 \\
\hline Serine & 1.31 & 1.26 & 1.29 & 1.23 \\
\hline
\end{tabular}

${ }^{1} \mathrm{AEE}=$ acid hydrolyzed ether extract.

${ }^{2}$ Calculated by expressing the concentration of Lysine in each ingredient as a percentage of the concentration of CP [23].

${ }^{3}$ Reactive Lysine $(\%)=[$ Lysine $(\%)-($ Furosine $(\%) \div 0.32 \times 0.40)]$; [2].

${ }^{4} A D I N$, acid detergent insoluble nitrogen.

on the AID and SID of AA were analyzed by orthogonal polynomial contrasts. Correlations among predictor variables or between predictor variables and dependent variables were determined using the CORR procedure of SAS. The coefficients of correlation $\left(\mathrm{r}_{\mathrm{p}}\right)$ were divided into 4 groups: no correlation $(P>0.05)$, low correlation $\left(r_{p}<0.30\right)$, moderate correlation $\left(0.60>r_{p} \geq 0.30\right)$, or high correlation $\left(r_{p} \geq 0.60\right)$. Regression equations to estimate the relationship between the concentration of SID AA and nutrient concentration were developed using the REG procedure in SAS. The pig was the experimental unit for all analyses and significance among means was assessed with an $\alpha$ level of 0.05 .

\section{Results}

Heat treatment did not change the concentrations of DM, ash, or CP in DDGS (Table 1). The concentration of total Lysine, however, was $0.82 \%$ in non-autoclaved 
Table 2 Ingredient composition of experimental diets, as-fed basis

\begin{tabular}{|c|c|c|c|c|c|}
\hline \multirow[b]{3}{*}{ Ingredient, \% } & \multicolumn{4}{|c|}{ Distillers dried grains with solubles diets } & \multirow[b]{3}{*}{$\mathrm{N}$-free die } \\
\hline & \multirow[b]{2}{*}{ Non-autoclaved } & \multicolumn{3}{|c|}{ Autoclaved at $130^{\circ} \mathrm{C}$} & \\
\hline & & $10 \min$ & $20 \min$ & $30 \mathrm{~min}$ & \\
\hline $\mathrm{DDGS}^{1}$ & 60.00 & 60.00 & 60.00 & 60.00 & - \\
\hline Cornstarch & 27.00 & 27.00 & 27.00 & 27.00 & 66.40 \\
\hline Sucrose & 10.00 & 10.00 & 10.00 & 10.00 & 20.00 \\
\hline Solka floc ${ }^{2}$ & - & - & - & - & 5.00 \\
\hline Soybean oil & - & - & - & - & 4.00 \\
\hline Ground limestone & 1.20 & 1.20 & 1.20 & 1.20 & - \\
\hline Dicalcium phosphate & 0.60 & 0.60 & 0.60 & 0.60 & 3.00 \\
\hline Sodium chloride & 0.40 & 0.40 & 0.40 & 0.40 & 0.40 \\
\hline Magnesium oxide & - & - & - & - & 0.10 \\
\hline Potassium carbonate & - & - & - & - & 0.40 \\
\hline Chromic oxide & 0.40 & 0.40 & 0.40 & 0.40 & 0.40 \\
\hline Vitamin-mineral premix ${ }^{3}$ & 0.40 & 0.40 & 0.40 & 0.40 & 0.30 \\
\hline
\end{tabular}

DDGS and $0.65,0.73$, and $0.68 \%$ in the DDGS that was autoclaved for 10,20 , and $30 \mathrm{~min}$, respectively. The calculated concentration of reactive Lysine was 0.80, $0.64,0.72$, and $0.67 \%$ for non-autoclaved DDGS and DDGS that was autoclaved for 10,20 , and $30 \mathrm{~min}$, respectively. The Lysine:CP ratio was 2.94 in nonautoclaved DDGS, whereas the Lysine:CP ratio was 2.37, 2.75, and 2.51 in the batches that were autoclaved for 10,20 , and $30 \mathrm{~min}$, respectively. The ADF concentration was $7.96 \%$ in non-autoclaved DDGS, whereas for autoclaved DDGS, the concentration of ADF was 11.05, 9.85, and 10.89\% (10, 20, and $30 \mathrm{~min}$, respectively). The concentration of ADIN in nonautoclaved DDGS was $0.12 \%$, whereas the concentration of ADIN ranged from 0.42 to $0.55 \%$ in the autoclaved DDGS. Reducing sugar concentration was 0.78 in non-autoclaved DDGS, but DDGS that was autoclaved for 10, 20, and $30 \mathrm{~min}$ contained 0.60, 0.88, and $0.65 \%$ reducing sugars, respectively.

\section{Digestibility of $\mathrm{CP}$ and $\mathrm{AA}$}

The AID of CP decreased (linear, $P<0.05$ ) from $64.4 \%$ in the non-autoclaved DDGS to 59.0, 52.2, and $55.7 \%$ in the DDGS that was autoclaved for 10, 20, or $30 \mathrm{~min}$, respectively (Table 4). The AID of Ile, Lysine, Methionine, Phenylalanine, and Aspartic acid was reduced (quadratic, $P<0.05$ ) with increasing time of autoclaving, whereas the AID of all other AA was reduced (linear, $P<0.05$ ) with increasing time of autoclaving. Lysine was the AA most affected by increasing time of autoclaving. The AID of Lysine was reduced (quadratic, $P<$ 0.05 ) from 61.2 to $48.0,48.7$, and $44.9 \%$ for the nonautoclaved DDGS and the DDGS that was autoclaved for 10,20 , or $30 \mathrm{~min}$, respectively. The mean AID of indispensable AA was reduced (linear, $P<0.05$ ) as time of autoclaving increased.

The SID of CP decreased (linear, $P<0.05$ ) from $77.9 \%$ in the non-autoclaved DDGS to $72.1,66.1$, and $68.5 \%$ in the DDGS that was autoclaved for 10,20 , or $30 \mathrm{~min}$, respectively (Table 5). The SID of Lysine was reduced (quadratic, $P<0.05$ ) from $66.8 \%$ in the non-autoclaved DDGS to $54.9,55.3$, and $51.9 \%$ in the DDGS that was autoclaved for 10,20 , or $30 \mathrm{~min}$, respectively.

The SID of Isoleucine, Methionine, Phenylalanine, and Aspartic acid also was reduced (quadratic, $P<0.05$ ) with increasing time of autoclaving, whereas the SID of all other AA was reduced (linear, $P<0.05$ ) with increasing time of autoclaving. The mean SID of indispensable AA also was reduced (linear, $P<0.05$ ) as time of autoclaving increased.

Coefficients of linear correlation and regression equations The concentrations of SID AA were correlated $\left(\mathrm{r}_{\mathrm{p}}>\right.$ $0.70 ; P<0.01)$ with the Lysine:CP ratio, except for the concentration of SID Threonine, which was only 
Table 3 Analyzed composition of experimental diets, as-fed basis

\begin{tabular}{|c|c|c|c|c|c|}
\hline \multirow[b]{3}{*}{ Item } & \multicolumn{4}{|c|}{ Distillers dried grains with solubles } & \multirow[b]{3}{*}{$\mathrm{N}$-free die } \\
\hline & \multirow[b]{2}{*}{ Non-autoclaved } & \multicolumn{3}{|c|}{ Autoclaved at $130^{\circ} \mathrm{C}$} & \\
\hline & & $10 \mathrm{~min}$ & $20 \mathrm{~min}$ & $30 \mathrm{~min}$ & \\
\hline Dry matter, \% & 92.42 & 93.18 & 92.59 & 92.32 & 92.53 \\
\hline Crude protein (CP), \% & 14.96 & 15.59 & 14.62 & 15.76 & 0.28 \\
\hline \multicolumn{6}{|l|}{ Indispensable AA, \% } \\
\hline Arginine & 0.73 & 0.68 & 0.70 & 0.67 & - \\
\hline Histidine & 0.42 & 0.41 & 0.42 & 0.41 & - \\
\hline Isoleucine & 0.56 & 0.57 & 0.58 & 0.55 & - \\
\hline Leucine & 1.69 & 1.75 & 1.76 & 1.72 & - \\
\hline Lysine & 0.51 & 0.42 & 0.44 & 0.41 & - \\
\hline Methionine & 0.31 & 0.29 & 0.29 & 0.28 & - \\
\hline Phenylalanine & 0.71 & 0.73 & 0.74 & 0.72 & - \\
\hline Threonine & 0.61 & 0.61 & 0.62 & 0.60 & - \\
\hline Tryptophan & 0.13 & 0.12 & 0.12 & 0.12 & - \\
\hline Valine & 0.74 & 0.75 & 0.76 & 0.73 & - \\
\hline \multicolumn{6}{|l|}{ Dispensable AA, \% } \\
\hline Alanine & 1.11 & 1.14 & 1.15 & 0.12 & - \\
\hline Aspartic acid & 1.05 & 1.04 & 1.06 & 1.03 & - \\
\hline Cysteine & 0.33 & 0.32 & 0.31 & 0.31 & - \\
\hline Glutamic acid & 2.60 & 2.69 & 2.70 & 2.65 & - \\
\hline Glycine & 0.64 & 0.65 & 0.66 & 0.64 & - \\
\hline Proline & 1.30 & 1.24 & 1.27 & 1.23 & - \\
\hline Serine & 0.78 & 0.79 & 0.79 & 0.78 & - \\
\hline
\end{tabular}

moderately correlated with the Lysine:CP ratio (Table 6). The concentration of SID AA was poorly correlated $\left(r_{p}<\right.$ $0.50)$ with the concentration of reducing sugars. The concentrations of SID AA were negatively correlated with the concentrations of ADF, NDF, lignin, and ADIN $(P<0.01)$. The concentration of SID of each AA also was well correlated $\left(r_{p}>0.65 ; P<0.01\right)$ with its respective concentration of total AA, except for SID Threonine, which was only moderately correlated $\left(\mathrm{r}_{\mathrm{p}}<0.65 ; P<0.01\right)$ with the concentration of total Threonine.

The concentrations of digestible AA may be predicted by regression equations presented in Table 7 . The concentration of SID Arginine or SID Lysine were best predicted by equations that included the concentration of ADIN in the model $\left(r^{2}=0.76\right.$ and 0.84 , respectively). The concentration of most SID AA was predicted $\left(\mathrm{r}^{2}>\right.$ 0.50 ) by the concentration of each total AA, but the concentration of SID Threonine was poorly $\left(r^{2}=0.36\right)$ predicted by the concentration of Threonine.

\section{Discussion}

Composition of distillers dried grains with solubles

The concentrations of DM, ash, and CP were not affected by autoclaving DDGS and this observation supports results of González-Vega et al. [4] who reported that autoclaving soybean meal did not change concentrations of DM, ash, or CP. Changes in the concentration of Lysine observed for autoclaved DDGS in this experiment also agree with results of previous experiments in which the concentration of Lysine was decreased by heat treatment $[2,3,6,22]$. Based on the concentration of Lysine, these results indicate that autoclaving corn DDGS for $10 \mathrm{~min}$ was sufficient to cause heat damage, but increasing time of autoclaving to 20 and $30 \mathrm{~min}$ did not result in further decreases in Lysine concentration. In contrast, in a previous experiment, the concentration of Lysine in corn DDGS autoclaved for 0, 10,20 , or $30 \mathrm{~min}$ at $135^{\circ} \mathrm{C}$ was linearly decreased from 0.82 to $0.59 \%$ [6]. These differences may be a result of differences in sample preparation and autoclaving procedures. Although temperature and time of autoclaving were similar between the 2 experiments, in this experiment, DDGS was autoclaved on an as-is basis in quantities of $2.5 \mathrm{~kg}$ per tray whereas Fontaine et al. [6] ground DDGS to $<3 \mathrm{~mm}$ particle size and then autoclaved DDGS in $250 \mathrm{~g}$ quantities. The concentrations of furosine in DDGS used in this experiment were slightly less than the average concentration of furosine $(0.02 \%$; 
Table 4 Apparent ileal digestibility of crude protein (CP) and AA in distillers dried grains with solubles subjected to increasing levels of heat treatment by weanling pigs ${ }^{1}$

\begin{tabular}{|c|c|c|c|c|c|c|c|}
\hline \multirow[b]{3}{*}{ Item } & \multicolumn{4}{|c|}{ Distillers dried grains with solubles } & \multirow{3}{*}{ SEM } & \multirow{2}{*}{\multicolumn{2}{|c|}{$P$-value ${ }^{2}$}} \\
\hline & \multirow[b]{2}{*}{ Non-autoclaved } & \multicolumn{3}{|c|}{ Autoclaved at $130^{\circ} \mathrm{C}$} & & & \\
\hline & & $10 \mathrm{~min}$ & $20 \mathrm{~min}$ & $30 \mathrm{~min}$ & & Linear & Quadratic \\
\hline $\mathrm{CP}, \%$ & 64.4 & 59.0 & 52.2 & 55.7 & 2.0 & $<0.01$ & 0.12 \\
\hline \multicolumn{8}{|c|}{ Indispensable AA, \% } \\
\hline Arginine & 79.3 & 71.9 & 72.0 & 69.1 & 1.7 & $<0.01$ & 0.06 \\
\hline Histidine & 73.9 & 66.8 & 65.9 & 66.0 & 1.3 & $<0.01$ & 0.23 \\
\hline Isoleucine & 72.3 & 66.2 & 66.6 & 63.1 & 1.4 & $<0.01$ & 0.02 \\
\hline Leucine & 84.0 & 80.7 & 80.4 & 79.1 & 0.8 & $<0.01$ & 0.12 \\
\hline Lysine & 61.2 & 48.0 & 48.7 & 44.9 & 1.9 & $<0.01$ & 0.02 \\
\hline Methionine & 83.6 & 77.7 & 77.8 & 75.7 & 0.9 & $<0.01$ & $<0.01$ \\
\hline Phenylalanine & 79.8 & 75.1 & 75.4 & 73.6 & 1.0 & $<0.01$ & 0.04 \\
\hline Threonine & 60.2 & 53.9 & 53.2 & 51.2 & 1.6 & $<0.01$ & 0.27 \\
\hline Tryptophan & 55.1 & 43.7 & 42.8 & 41.5 & 2.0 & $<0.01$ & 0.15 \\
\hline Valine & 71.9 & 65.7 & 65.5 & 62.6 & 1.4 & $<0.01$ & 0.08 \\
\hline Mean & 75.6 & 70.0 & 69.9 & 67.8 & 1.1 & $<0.01$ & 0.07 \\
\hline \multicolumn{8}{|l|}{ Dispensable AA, \% } \\
\hline Alanine & 77.5 & 73.3 & 71.4 & 71.0 & 1.3 & $<0.01$ & 0.86 \\
\hline Aspartic acid & 65.5 & 55.2 & 55.4 & 53.3 & 1.5 & $<0.01$ & 0.02 \\
\hline Cysteine & 71.9 & 64.7 & 60.5 & 62.7 & 1.5 & $<0.01$ & 0.54 \\
\hline Glutamic acid & 81.7 & 76.7 & 75.6 & 75.3 & 0.9 & $<0.01$ & 0.34 \\
\hline Glycine & 43.4 & 36.3 & 29.0 & 31.7 & 4.6 & $<0.01$ & 0.47 \\
\hline Proline & 69.6 & 65.1 & 64.1 & 63.2 & 1.3 & $<0.01$ & 0.47 \\
\hline Mean & 68.3 & 61.8 & 59.2 & 59.5 & 1.5 & $<0.01$ & 0.85 \\
\hline
\end{tabular}

${ }^{1}$ Data are means of 8 observations, except for the distillers dried grains with solubles diet that was autoclaved for $10 \mathrm{~min}(\mathrm{n}=7)$.

${ }^{2}$ Linear and quadratic effects of time of autoclaving.

$\mathrm{CV}=91.4 \%)$ measured in 21 sources of DDGS, and these differences may be a result of the high degree of variation when determining the concentration of furosine in DDGS [8]. The reason for the reduced Lysine:CP ratio in the autoclaved DDGS is that only the concentration of Lysine, but not the concentration of $\mathrm{CP}$, is reduced when heat damage occurs $[8,23]$. The Lysine:CP ratio also was reduced in soybean meal that was heatdamaged compared with unheated soybean meal [4]. The concentration of Lysine in the non-autoclaved DDGS was slightly greater than the average concentration of Lysine $(0.76 \%)$ in 39 sources of DDGS [24]. Likewise, the Lysine:CP ratio was slightly greater in the unheated DDGS compared with the average value (2.77) reported previously [24]. However, the concentrations of Lysine and the Lysine:CP ratio in autoclaved DDGS are close to the average values reported by Stein and Shurson [24] for corn DDGS, which indicates that the heat damage caused by autoclaving simulated the varying degrees of heat damage caused by processing of DDGS in commercial production facilities.
The concentration of ADIN has been used as a predictor of heat damage in plant proteins and our results agree with these observations [25]. The changes observed between the concentrations of reducing sugars in the unheated DDGS and the 3 autoclaved DDGS were expected because, in the initial steps of the Maillard reactions, reducing sugars react with the $\varepsilon$-amino group of Lysine to form fructoselysine and maltuloselysine, respectively [26].

\section{Digestibility of $\mathrm{CP}$ and $\mathrm{AA}$}

Values for the AID of CP and AA in the DDGS that was not autoclaved are in agreement with results from previous experiments [11,24]. Results of previous experiments also indicated that the digestibility of Lysine was more reduced by heat damage than the digestibility of other AA $[4,22]$. Values for the SID of CP and AA in the nonautoclaved DDGS were within the range of values for the SID of CP and AA in corn DDGS observed in previous experiments [24]. This observation is supported by the value for the Lysine:CP ratio (2.94) determined for 
Table 5 Standardized ileal digestibility of crude protein (CP) and AA in distillers dried grains with solubles subjected to increasing levels of heat treatment by weanling pigs ${ }^{1}$

\begin{tabular}{|c|c|c|c|c|c|c|c|}
\hline \multirow[b]{3}{*}{ Item } & \multicolumn{4}{|c|}{ Distillers dried grains with solubles } & \multirow{3}{*}{ SEM } & \multirow{2}{*}{\multicolumn{2}{|c|}{$P$-value ${ }^{2}$}} \\
\hline & \multirow[b]{2}{*}{ Non-autoclaved } & \multicolumn{3}{|c|}{ Autoclaved at $130^{\circ} \mathrm{C}$} & & & \\
\hline & & $10 \mathrm{~min}$ & $20 \mathrm{~min}$ & $30 \mathrm{~min}$ & & Linear & Quadratic \\
\hline$C P, \%$ & 77.9 & 72.1 & 66.1 & 68.5 & 2.0 & $<0.01$ & 0.25 \\
\hline \multicolumn{8}{|c|}{ Indispensable AA, \% } \\
\hline Arginine & 87.9 & 81.3 & 81.0 & 78.5 & 1.7 & $<0.01$ & 0.11 \\
\hline Histidine & 78.1 & 71.2 & 70.1 & 70.3 & 1.3 & $<0.01$ & 0.27 \\
\hline Isoleucine & 77.3 & 71.1 & 71.4 & 68.2 & 1.4 & $<0.01$ & 0.03 \\
\hline Leucine & 86.7 & 83.3 & 83.1 & 81.8 & 0.8 & $<0.01$ & 0.12 \\
\hline Lysine & 66.8 & 54.9 & 55.3 & 51.9 & 1.9 & $<0.01$ & 0.04 \\
\hline Methionine & 86.1 & 80.4 & 80.5 & 78.5 & 0.9 & $<0.01$ & $<0.01$ \\
\hline Phenylalanine & 83.7 & 79.0 & 79.2 & 77.5 & 1.0 & $<0.01$ & 0.05 \\
\hline Threonine & 70.2 & 64.0 & 63.1 & 61.3 & 1.6 & $<0.01$ & 0.33 \\
\hline Tryptophan & 65.9 & 55.5 & 54.5 & 53.2 & 2.0 & $<0.01$ & 0.20 \\
\hline Valine & 77.2 & 71.0 & 70.7 & 67.9 & 1.4 & $<0.01$ & 0.09 \\
\hline Mean & 80.7 & 75.2 & 74.9 & 73.1 & 1.1 & $<0.01$ & 0.09 \\
\hline \multicolumn{8}{|c|}{ Dispensable AA, \% } \\
\hline Alanine & 83.3 & 79.1 & 77.1 & 76.8 & 1.3 & $<0.01$ & 0.89 \\
\hline Aspartic acid & 72.3 & 62.1 & 62.1 & 60.2 & 1.5 & $<0.01$ & 0.03 \\
\hline Cysteine & 77.7 & 70.8 & 66.8 & 68.9 & 1.5 & $<0.01$ & 0.55 \\
\hline Glutamic acid & 85.2 & 80.1 & 79.0 & 78.7 & 0.9 & $<0.01$ & 0.33 \\
\hline Glycine & 73.4 & 66.0 & 58.1 & 61.7 & 4.6 & $<0.01$ & 0.39 \\
\hline Proline & 76.9 & 72.4 & 71.3 & 70.5 & 1.3 & $<0.01$ & 0.48 \\
\hline Mean & 78.1 & 71.7 & 69.0 & 69.4 & 1.5 & $<0.01$ & 0.91 \\
\hline
\end{tabular}

${ }^{1}$ Data are means of 8 observations, except for the distillers dried grains with solubles diet that was autoclaved for 10 min $(n=7)$; Values for standardized ileal digestibility were calculated by correcting apparent ileal digestibility values for basal endogenous losses ( $\mathrm{g} / \mathrm{kg}$ of DMI), which were determined by feeding pigs a $\mathrm{N}$-free diet: CP, 21.93; Arginine, 0.68; Histidine, 0.19; Isoleucine, 0.30; Leucine, 0.50; Lysine, 0.31; Methionine, 0.08; Phenylalanine, 0.30; Threonine, 0.66; Tryptophan, 0.15; Valine, 0.43; Alanine, 0.71; Aspartic acid, 0.77; Cysteine, 0.21; Glutamic acid, 0.98; Glycine, 2.08; and Serine, 0.62.

${ }^{2}$ Linear and quadratic effects of time of autoclaving.

corn DDGS in this experiment, which is in agreement with the average value (2.77) reported previously [24]. For the autoclaved DDGS, however, values for the SID of $\mathrm{CP}$ and AA were less than those reported by Stein and Shurson [24]. Reductions observed for the SID of Lysine with increasing time of autoclaving and the results from reducing sugars and the Lysine concentrations in autoclaved DDGS indicate that the conditions created by autoclaving of DDGS (i.e., heat, moisture, and pressure) were favorable to initiation of Maillard reactions, which renders Lysine unavailable to the animals and, therefore, reduces Lysine digestibility $[4,27]$. This indicates that heating alone may not be detrimental to the nutritional quality of DDGS, unless combined with a certain degree of moisture. The nutritional quality of soybean meal heat-processed in conventional oven was not different from that of conventional soybean meal, which is in agreement with the latter assumption [4]. It appears, however, that the degree of heat damage among autoclaved DDGS (i.e., 10, 20, or $30 \mathrm{~min}$ ) was not different and this observation is supported by the fact that the SID of Lysine among these ingredients was not different. Reductions in the digestibility of AA other than Lysine have been attributed to the formation of cross-linkages between protein chains [28]. When these cross-links are formed, digestive enzymes such as trypsin have reduced access to the proteins, thus the ability of trypsin to hydrolyze peptide bonds is reduced. Exposure to excessive heat and pressure may also lead to AA racemization, thus converting L-AA to D-AA [29]. Proteolytic enzymes are unable to hydrolyze peptide bonds connecting $\mathrm{D}-\mathrm{AA}$ and L-AA. Consequently, the digestibility is reduced not only for the D-AA, but also for the L-AA [30].

Coefficients of linear correlation and regression equations The relatively good correlations between the concentration of SID AA and the concentration of each AA in DDGS agree with previous results [8]. Consequently, 
Table 6 Coefficients of linear correlation between nutrient composition of distillers dried grains with solubles and the concentration (\%) of standardized ileal digestible (SID) AA $^{1}$

\begin{tabular}{|c|c|c|c|c|c|c|c|c|c|c|c|c|c|c|c|c|}
\hline \multirow[b]{3}{*}{ Item } & \multicolumn{16}{|c|}{ Nutrient composition } \\
\hline & Lys:CP & Reducing sugars & ADF & NDF & Lignin & $\mathrm{ADIN}^{2}$ & Arg & His & Ile & Leu & Lys & Met & Phe & Thr & Trp & Val \\
\hline & & & & & & & & & & & & & & & & \\
\hline SID Arg & $0.80^{*}$ & $0.50^{*}$ & $-0.86^{*}$ & $-0.60^{*}$ & $-0.62^{*}$ & $-0.87^{*}$ & $0.84^{*}$ & - & - & - & - & - & - & - & - & - \\
\hline SID His & $0.72^{*}$ & $0.06^{\mathrm{ns}}$ & $-0.81^{*}$ & $-0.69^{*}$ & $-0.48^{*}$ & $-0.82^{*}$ & - & $0.69^{*}$ & - & - & - & - & - & - & - & - \\
\hline SID lle & $0.76^{*}$ & $0.49^{*}$ & $-0.81^{*}$ & $-0.58^{*}$ & $-0.55^{*}$ & $-0.81^{*}$ & - & - & $0.70^{*}$ & - & - & - & - & - & - & - \\
\hline SID Leu & $0.72^{*}$ & $0.45^{* *}$ & $-0.81^{*}$ & $-0.54^{*}$ & $-0.65^{*}$ & $-0.82^{*}$ & - & - & - & $0.78^{*}$ & - & - & - & - & - & - \\
\hline SID Lys & $0.83^{*}$ & $0.45^{* *}$ & $-0.91^{*}$ & $-0.74^{*}$ & $-0.54^{*}$ & $-0.92^{*}$ & - & - & - & - & $0.89^{*}$ & - & - & - & - & - \\
\hline SID Met & $0.78^{*}$ & $0.40^{* *}$ & $-0.86^{*}$ & $-0.73^{*}$ & $-0.48^{*}$ & $-0.87^{*}$ & - & - & - & - & - & $0.75^{*}$ & - & - & - & - \\
\hline SID Phe & $0.78^{*}$ & $0.47^{*}$ & $-0.85^{*}$ & $-0.63^{*}$ & $-0.56^{*}$ & $-0.86^{*}$ & - & - & - & - & - & - & $0.83^{*}$ & - & - & - \\
\hline SID Thr & $0.58^{*}$ & $0.25^{\mathrm{ns}}$ & $-0.70^{*}$ & $-0.55^{*}$ & $-0.56^{*}$ & $-0.73^{*}$ & - & - & - & - & - & - & - & $0.60^{*}$ & - & - \\
\hline SID Trp & $0.71^{*}$ & $0.34^{\mathrm{ns}}$ & $-0.81^{*}$ & $-0.70^{*}$ & $-0.52^{*}$ & $-0.83^{*}$ & - & - & - & - & - & - & - & - & $0.84^{*}$ & - \\
\hline SID Val & $0.73^{*}$ & $0.45^{* *}$ & $-0.78^{*}$ & $-0.59^{*}$ & $-0.50^{*}$ & $-0.78^{*}$ & - & - & - & - & - & - & - & - & - & $0.55^{\circ}$ \\
\hline
\end{tabular}

${ }^{1} \mathrm{Arg}$, Arginine; His, Histidine; Ile, Isoleucine; Leu, Leucine; Lys, Lysine; Met, Methionine; Phe, Phenylalanine; Thr, Threonine; Trp, Tryptophan; Val, Valine. ${ }^{2} A D I N$, acid detergent insoluble nitrogen.

${ }^{*}=P<0.01 ;{ }^{* *}=P<0.05 ; \mathrm{ns}=$ not significant.

Table 7 Linear regression to predict the concentration (\%) of standardized ileal digestible (SID) AA from the nutrient concentrations $(\%)$ in corn distillers dried grains with solubles (DDGS) fed to pigs ${ }^{1}$

\begin{tabular}{|c|c|c|c|c|c|c|c|c|}
\hline \multirow[b]{2}{*}{ Dependent variable } & \multicolumn{3}{|c|}{ Intercept } & \multicolumn{4}{|c|}{ Independent variable $^{2}$} & \multirow[b]{2}{*}{$r^{2}$} \\
\hline & Estimate & SE & $P$-value & Variable & Estimate & SE & $P$-value & \\
\hline \multirow[t]{2}{*}{ SID Arginine } & -0.66 & 0.20 & $<0.01$ & $\operatorname{Arg}$ & 1.398 & 0.171 & $<0.01$ & 0.70 \\
\hline & 1.16 & 0.02 & $<0.01$ & ADIN & -0.506 & 0.053 & $<0.01$ & 0.76 \\
\hline \multirow[t]{2}{*}{ SID Histidine } & -0.62 & 0.22 & $<0.01$ & His & 1.639 & 0.322 & $<0.01$ & 0.47 \\
\hline & 0.58 & 0.01 & $<0.01$ & ADIN & -0.203 & 0.025 & $<0.01$ & 0.68 \\
\hline \multirow[t]{2}{*}{ SID Isoleucine } & -0.92 & 0.30 & $<0.01$ & Ile & 1.706 & 0.320 & $<0.01$ & 0.50 \\
\hline & 0.15 & 0.08 & 0.08 & Lys:CP & 0.200 & 0.031 & $<0.01$ & 0.58 \\
\hline \multirow[t]{2}{*}{ SID Leucine } & -2.23 & 0.69 & $<0.01$ & Leu & 1.623 & 0.243 & $<0.01$ & 0.61 \\
\hline & 2.61 & 0.03 & $<0.01$ & ADIN & -0.554 & 0.071 & $<0.01$ & 0.67 \\
\hline \multirow[t]{2}{*}{ SID Lysine } & -0.46 & 0.08 & $<0.01$ & Lys & 1.214 & 0.115 & $<0.01$ & 0.79 \\
\hline & 0.60 & 0.02 & $<0.01$ & ADIN & -0.463 & 0.037 & $<0.01$ & 0.84 \\
\hline \multirow[t]{2}{*}{ SID Methionine } & -0.39 & 0.13 & $<0.01$ & Met & 1.53 & 0.252 & $<0.01$ & 0.56 \\
\hline & 0.46 & 0.01 & $<0.01$ & ADIN & -0.161 & 0.017 & $<0.01$ & 0.76 \\
\hline \multirow[t]{2}{*}{ SID Phenylalanine } & -1.11 & 0.26 & $<0.01$ & Phe & 1.726 & 0.217 & $<0.01$ & 0.68 \\
\hline & 1.08 & 0.01 & $<0.01$ & ADIN & -0.304 & 0.034 & $<0.01$ & 0.73 \\
\hline \multirow[t]{2}{*}{ SID Threonine } & -1.31 & 0.50 & $<0.05$ & Thr & 1.967 & 0.499 & $<0.01$ & 0.36 \\
\hline & 0.75 & 0.02 & $<0.01$ & ADIN & -0.247 & 0.043 & $<0.01$ & 0.54 \\
\hline \multirow[t]{2}{*}{ SID Tryptophan } & -0.24 & 0.04 & $<0.01$ & Trp & 1.767 & 0.219 & $<0.01$ & 0.70 \\
\hline & -0.04 & 0.03 & 0.19 & Lys:CP & 0.061 & 0.011 & $<0.01$ & 0.51 \\
\hline \multirow[t]{2}{*}{ SID Valine } & -0.88 & 0.50 & 0.08 & Val & 1.438 & 0.400 & $<0.01$ & 0.31 \\
\hline & 0.24 & 0.11 & 0.04 & Lys:CP & 0.246 & 0.042 & $<0.01$ & 0.54 \\
\hline
\end{tabular}

${ }^{1} \mathrm{n}=31$ observations; for all models $P<0.01$.

${ }^{2} A D I N$, acid detergent insoluble nitrogen; Arg, Arginine; His, Histidine; Ile, Isoleucine; Leu, Leucine; Lys, Lysine; Met, Methionine; Phe, Phenylalanine; Thr, Threonine; Trp, Tryptophan; Val, Valine. 
analyzed concentrations of most AA in DDGS may be used to predict the concentration of SID AA in DDGS although that is not the case for Threonine. It has been observed that heat damage of feed ingredients is associated with an increase in analyzed values for ADF, lignin, and ADIN, which results in a decrease in $\mathrm{N}$ digestibility in cattle and sheep [30]. The concentrations of ADF and ADIN is increased in dark-colored DDGS, which indicates a greater degree of heat damage in such ingredients [10], and likely a lower digestibility of AA. The negative correlation between the concentration of SID AA and the concentrations of ADF, lignin, or ADIN observed in this experiment support the latter observations.

The concentration of SID Lysine can accurately be predicted from the concentration of Lysine. This observation agrees with Kim et al. [8]. Prediction of the concentration of SID Lysine in this study was slightly improved if the concentration of ADIN was used in the model. This indicates that the concentration of analyzed ADIN may be used to predict the concentration of SID Lysine in DDGS.

\section{Conclusions}

Results of this experiment confirmed that the concentration and digestibility of AA in DDGS is reduced as a result of heat damage. The concentrations of Lysine and ADIN are good predictors of the concentration of most AA in heat-damaged DDGS, which indicates that such predictors may be used as indicators of the protein quality in DDGS. These equations, however, must be validated using different sources of DDGS.

\section{Abbreviations \\ AA: Amino acids; ADF: Acid detergent fibre; ADIN: Acid detergent insoluble nitrogen; AID: Apparent ileal digestibility; BW: Body weight; CDS: Condensed solubles; CP: Crude protein; CV: Coefficient of variation; DDGS: Distillers dried grains with solubles; DM: Dry matter; HPLC: High performance liquid chromatography; ME: Metabolizable energy; NDF: Neutral detergent fibre; SID: Standardized ileal digestibility.}

\section{Competing interests}

The authors declare that they have no competing interests.

\section{Authors' contributions}

All authors read and approved the final manuscript.

\section{Acknowledgements}

Financial support for this research from Enonik Industries AG, Rodenbacher Chaussee 4, 63457, Hanau, Germany, is appreciated.

\section{Author details}

'Department of Animal Sciences, University of Illinois, 1207 W Gregory Dr, Urbana, IL 61801, USA. ²Evonik Industries AG, Rodenbacher Chaussee 4, Hanau 63457, Germany. ${ }^{3}$ Evonik Degussa Corporation, 1701 Barrett Lakes Blvd NW, Kennesaw, GA 30144, USA.

Received: 4 June 2013 Accepted: 11 November 2013

Published: 14 November 2013

\section{References}

1. Rosentrater KA, lleleji K, Johnston DB: Manufacturing of fuel ethanol and distillers grains - current and evolving process. In Distillers Grains Production, Properties, and Utilization. Edited by Liu K, Rosentrater KA. Boca Raton, FL: CRC Press; 2012:73-102.

2. Pahm AA, Pedersen $\mathrm{C}$, Stein $\mathrm{HH}$ : Application of the reactive lysine procedure to estimate lysine digestibility in distillers dried grains with solubles fed to growing pigs. J Agric Food Chem 2008, 56:9441-9446.

3. Boucher SE, Pedersen C, Stein HH, Schwab CG: Evaluation of the furosine and homoarginine methods for determining reactive Lys in rumenundegraded protein. J Dairy Sci 2009, 92:3951-3958.

4. González-Vega JC, Kim BG, Htoo JK, Lemme A, Stein HH: Amino acid digestibility in heated soybean meal fed to growing pigs. J Anim Sci 2011, 89:3617-3625.

5. Rutherfurd SM, Moughan PJ: Development of a novel bioassay for determining the available Lys contents of foods and feedstuffs. Nutr Res Rev 2007, 20:3-16.

6. Fontaine J, Zimmer U, Moughan PJ, Rutherfurd SM: Effect of heat damage in an autoclave on the reactive lysine contents of soy products and corn distillers dried grains with solubles. Use of the results to check on lysine damage in common qualities of these ingredients. J Agric Food Chem 2007, 55:10737-10743.

7. Cozannet P, Primot Y, Gady C, Métayer JP, Callu P, Lessire M, Skiba F, Noblet J: Ileal digestibility of amino acids in wheat distillers dried grains with solubles for pigs. Anim Feed Sci Technol 2010, 158:177-186.

8. Kim BG, Kil DY, Zhang Y, Stein $\mathrm{HH}$ : Concentrations of analyzed or reactive lysine, but not crude protein, may predict the concentration of digestible lysine in distillers dried grains with solubles (DDGS) fed to pigs. J Anim Sci 2012, 90:3798-3808.

9. Stein $\mathrm{HH}$ : Feeding ethanol coproducts to swine. In Distillers Grains Production, Properties, and Utilization. Edited by Liu K, Rosentrater KA. Boca Raton, FL: CRC Press; 2012:297-315.

10. Cromwell GL, Herkelman KL, Stahly TS: Physical, chemical, and nutritional characteristics of distillers dried grains with solubles for chicks and pigs. J Anim Sci 1993, 71:679-686.

11. Fastinger ND, Mahan DC: Determination of the ileal amino acid and energy digestibilities of corn distillers dried grains with solubles using grower-finisher pigs. J Anim Sci 2006, 84:1722-1728.

12. Stein $H H$, Shipley $C F$, Easter RA: Technical note: a technique for inserting a T-cannula into the distal ileum of pregnant sows. J Anim Sci 1998, 76:1433-1436.

13. NRC: Nutrient requirements of swine. 10th edition. Washington, DC: Natl Acad Press; 1998.

14. Llames $C R$, Fontaine J: Determination of amino-acids in feeds - collaborative study. J AOAC Int 1994, 77:1362-1402.

15. Directive C: Establishing community methods for the determination of amino acids, crude oils and fats, and olaquindox in feeding stuff and amending directive 71/393/EEC, annex part a. Determination of amino acids. Official J European Communities 1998, L257:14-23.

16. Directive $C$ : Establishing community methods for the determination of vitamin A, vitamin E and tryptophan, annex part C. Determination of Tryptophan. Official J European Communities 2000, L174:45-50.

17. AOAC: Official methods of analysis. 18th edition. Gaithersburg, MD: Association of Official Analytical Chemists; 2007.

18. Holst DO: Holst filtration apparatus for Van Soest detergent fiber analysis. J AOAC 1973, 56:1352-1356.

19. Sanderson P: A new method of analysis of feedstuffs for the determination of crude oils and fats. 1986. In Recent Advances in Animal Nutrition. Edited by Haresign W, Cole DJA. London, UK: Butterworths; 1986:77-81.

20. Dubois M, Gilles KA, Hamilton JK, Rebers PA, Smith F: Colorimetric method for determination of sugars and related substances. Anal Chem 1956, 28:350-356.

21. Stein HH, Seve B, Fuller MF, Moughan PJ, de Lange CFM: Invited review: Amino acid bioavailability and digestibility in pig feed ingredients: Terminology and application. J Anim Sci 2007, 85:172-180.

22. Martinez-Amezcua C, Parsons CM, Singh V, Srinivasan R, Murthy GS: Nutritional characteristics of corn distillers dried grains with solubles as affected by the amounts of grains versus solubles and different processing techniques. Poult Sci 2007, 86:2624-2630.

23. Stein $\mathrm{HH}$, Connot SP, Pedersen C: Energy and nutrient digestibility in four sources of distillers dried grains with solubles produced from corn 
grown within a narrow geographical area and fed to growing pigs. Asian-australas J Anim Sci 2009, 22:1016-1025.

24. Stein HH, Shurson GC: Board-invited review: The use and application of distillers dried grains with solubles in swine diets. J Anim Sci 2009, 87:1292-1303.

25. Schroeder GE, Erasmus LJ, Leeuw KJ, Meissner HH: The use of acid detergent insoluble nitrogen to predict digestibility of rumen undegradable protein of heat processed plant proteins. S Afr J Anim SCi 1996, 26:49-52.

26. Erbersdobler HF, Hupe A: Determination of lysine damage and calculation of lysine bio-availability in several processed foods. Z Ernahrungswiss 1991, 30:46-49.

27. Nursten H: The Maillard Reaction. Chemistry, Biochemistry, and Implications. Cambridge, UK: Royal Society of Chemistry; 2005.

28. Zagon J, Dehne LI, Bögl KW: D-amino acids in organisms and food. Nutr Res 1994, 14:445-463.

29. Finot PA: The absorption and metabolism of modified amino acids in processed foods. J AOAC Int 2005, 88:894-902.

30. Broesder JT, Gunter SA, Krysl LJ, Judkins MB: Digestion of ruminal masticate dried by three different methods. Anim Feed Sci Technol 1992, 37:323-331.

doi:10.1186/2049-1891-4-44

Cite this article as: Almeida et al: Amino acid digestibility of heat damaged distillers dried grains with solubles fed to pigs. Journal of Animal Science and Biotechnology 2013 4:44.

\section{Submit your next manuscript to BioMed Central and take full advantage of:}

- Convenient online submission

- Thorough peer review

- No space constraints or color figure charges

- Immediate publication on acceptance

- Inclusion in PubMed, CAS, Scopus and Google Scholar

- Research which is freely available for redistribution 